\title{
Effect of Nepeta cataria extract on the skin barrier function
}

\author{
Hyun-Soo Kim* \\ Department of Food Science and Technology, Jungwon University, Goesan 28024, Korea
}

개박하 추출물의 피부장벽 기능에 대한 효과

\author{
김현수* \\ 중원대학교 식품공학과
}

\begin{abstract}
Nepeta cataria commonly known as catnip, catswort, catwort, and catmint, is native to Europe, Asia, and America, and has a history of use in traditional medicine for a variety of ailments. Although $N$. cataria exhibits desirable biological effects, such as anti-microbial, anti-inflammatory, and anti-tumor activities, the effect of $N$. cataria extract on the skin barrier function remains unknown. Thus, we herein examined the application of functional materials by testing a variety of physiological activities of $N$. cataria extract. $N$. cataria extract was found to possess a low cytotoxicity and a high DPPH radical scavenging activity, which resulted in a significant increase in the transactivation activity of PPAR response elements (PPREs) such as peroxisome proliferator-activated receptor (PPAR)- $\alpha$. Finally, it was found that $N$. cataria extract promotes the expression of filaggrin and involucrin, which is related to skin barrier protection. These results indicate that $N$. cataria extract may be an effective comfound for improving the skin barrier function.
\end{abstract}

Key words : Nepeta cataria, PPAR- $\alpha$, filaggrin, involucrin

\section{서 론}

현대사회에서 증가하는 각종 오염물질, 중금속, 자외선 은 직접적으로 직업병을 유발함은 물론 간접적으로 주변 환경 등에 악영향을 주면서 궁극적으로 인체에 심각한 피해를 입히고 있을 뿐 아니라, 인체의 가장 체외 보호기관 인 피부에도 피부장벽손상(건조피부, 민감성피부, 노인성 건성피부, 아토피피부)을 유발한다. 피부장벽의 회복에 중 요한 역할을 한다고 알려져 있는 peroxisome proliferator activated receptor-alpha(PPAR- $\alpha$ )는 peroxisome proliferator activated receptor의 3 개의 아형 $(\alpha, \beta / \delta, \gamma)$ 중 하나인 핵수용 체로 retinoid X receptor(RXR)와 heterodimer를 이루어 다 양한 유전자의 전사를 조절하며, 세포 증식/분화의 조절,
염증 매개체들의 조절 등에 있어 중요한 역할을 담당하며, 포도당, 지질, 호르몬의 대사 조절에도 중요한 역할을 하는 것으로 보고되고 있다(Kersten 등, 2000). 즉, PPAR- $\alpha$ 는 표피의 분화와 표피 지질의 합성을 촉진함으로써 각질세 포와 각질세포간 지질막의 형성이라는 두 가지 기전을 통해 에너지 항상성을 조절하는 피부세포에 존재하는 인 자로서 피부 표피증식 억제 및 분화를 유도하며, 염증질환 치료 등 다양한 피부질환 핵심조절자로 작용하는 것으로 보고되고 있다(Hanley 등, 1997). 따라서 피부장벽 회복효 과를 가져올 수 있는 독성이 없는 천연소재 물질에 대한 개발이 요구되고 있다(Briganti 등, 2003).

본 연구의 재료인 개박하는 꿀풀과(Labiatae)에 속하는 식물로서 아시아, 유럽, 북아메리카 등에 분포하며, 수천년

*Corresponding author. E-mail : hyun1006@jwu.ac.kr, Phone : +82-43-830-8616, Fax : +82-43-830-8679

Received 03 January 2020; Revised 23 January 2020; Accepted 28 January 2020.

Copyright (c) The Korean Society of Food Preservation.

This is an Open Access article distributed under the terms of the Creative Commons Attribution Non-Commercial License (http://creativecommons.org/licenses/by-nc/4.0) which permits unrestricted non-commercial use, distribution, and reproduction in any medium, provided the original work is properly cited. 
동안 식품 및 전통의학용으로 사용되어 왔으며, 항균, 항 염, 항암효과가 있다고 알려져 있다(Wang 등, 2007). 이와 같이 많은 생리활성이 연구되고 있음에도 불구하고, 피부 장벽 개선효과를 비롯한 기능성 소재에 응용하기 위한 보고는 거의 없다. 따라서 본 연구에서는 개박하 추출시료 를 가지고 항산화, 세포독성 및 피부장벽 보호인자 생성 여부, 관련 단백질 발현 등 다양한 생리적 활성 연구를 진행하였으며 그 결과로 향후 기능성 소재로서의 응용 가능성을 제시하고자 하였다.

\section{재료 및 방법}

\section{실험재료}

개박하(Nepeta cataria)는 2019년 5월 경기도 화성시 소 재 농원에서 재배한 것을 직거래를 통하여 구입하였으며, 추출방법은 시료 30-40 g에 에탄올 $200 \mathrm{~mL}$ 를 첨가하고, 용매추출장치(ASE300 Accelerated Solvent Extractor, Dionex Corporation, Sunnyvale, USA)를 이용하여 $50^{\circ} \mathrm{C}, 1,500 \mathrm{psi}$ 에 서 20분 동안 추출하였다. 이후 건조기(Modul spin 40, Biotron Corporation, North Ryde, Australia)에서 $40^{\circ} \mathrm{C}$ 에서 24시간 동안 건조하고 실험에 사용하였다(Ahn 등, 2015).

\section{세포독성시험}

세포독성 시험은 $\operatorname{Kim}(2018)$ 의 연구에서 명기된 방법에 의해 수행하였다. 즉, 세포내의 미토콘드리아 수소제거효 소에 의해 수용테트라졸륨염(water soluble tetrazolium salts)(WST-1)에서 불용성의 포마진(formazan)결정으로 변 환되는 원리를 이용하였다. 포마진은 다이메틸설폭사이 드(dimethly sulfoxide)에 녹아서 보라색 빛을 띄는데 분광 광도계(spectrophotometer)로 $540 \mathrm{~nm}$ 파장에서 $\mathrm{OD}$ 값을 재 어서 정량하였다. 미국 세포주은행(ATCC, Manassas, VA, USA)에서 분양받은 멜라노마 세포(murine melanoma $\mathrm{B} 16 \mathrm{~F} 10$ )를 $10 \%$ 소태아 혈청(fetal bovine serum, FBS; Gibco, Waltham, MA, USA)이 포함된 dulbecco's Modified Eagle's medium(DMEM)에서 배양하고, 24 - well plate에 $2 \times 10^{4}$ cells/well 의 농도로 세포를 접종한 후, $37^{\circ} \mathrm{C}, 5 \%$ $\mathrm{CO}_{2}$ 조건에서 배양하였다. 이후 배양세포에 추출물을 농 도별로 처리하고 72시간 배양하였다(Ranke 등, 2004).

\section{Free radical scavenging 활성}

DPPH 라디칼(radical) 소거능 실험은 $\operatorname{Kim}(2018)$ 의 연구 에서 명기된 방법에 의해 수행하였다. 즉, $0.2 \mathrm{mM}$ 의 DPPH 용액 $0.8 \mathrm{~mL}$ 에 식물추출물 시료 $0.2 \mathrm{~mL}$ 를 첨가하여 혼합한 다음 실온에서 30 분간 반응시킨 후 $517 \mathrm{~nm}$ 에서 흡광도를 측정하였다. 대조구는 시료 대신 메탄올을 첨가하였고, positive control로 아스코빅산(ascorbic acid)를 사용하였다.
각 처리농도에서의 결과 수치로 $50 \%$ 저해 농도 $\left(\mathrm{ID}_{50}\right)$ 을 계산하여 DPPH 소거 활성 정도를 표현하였다. Free radical scavenging 활성은 [1 - (시료첨가구의 흡광도/무첨가구의 흡광도) $] \times 100$ 의 계산식에 의해 활성 $(\%)$ 을 구하였다.

\section{PPAR-a transcription 활성 측정}

PPAR- $\alpha$ transcription 활성측정은 transactivation assay 방 법으로 측정하였다(Kim 등, 2014). 한국세포주은행에서 구입한 CV-1 세포를 DMEM에서 배양하고 24 well plate에 $4 \times 10^{4}$ cells/well 의 농도로 배양한 후 일반적인 배양 조건에 서도 발현되는 universal promoter 뒤에 PPAR(유전자를 지 닌 것과 리간드 결합형의 PPAR)이 결합하여 활성화되는 PPRE(PPARs Response Element)를 프로모터로 가지는 PPAR- $\alpha$ Expression vector(Qiagen, Hilden, Germany)를 구입 하여 과발현시킨 것과, 리포터 역할을 하는 firefly luciferase 유전자 플라스미드와 참조로 사용될 유니버셜 프로모터에 Renilla luciferase 유전자가 결합된 플라스미드 (SABiosciences, Hilden, Germany)를 구입하여 lipofectamine(Invitrogen, Carlsbad, CA, USA)으로 transient transfection 시키고 시험 물질을 처리하고 추가 24시간 배양 후 1xPLB(Passive Lysis Buffer)로 세포를 분쇄한 후 DualLuciferase Reporter Assay System kit(Promega, Mannheim, Germany)를 사용하여 Luminometer로 luciferase 활성을 측 정하였다.

\section{Quantitative reverse transcription-PCR(qRT-PCR) 분석}

피부보호막 형성의 필수요소인 filaggrin 형성촉진을 확 인하고자 피부세포 배양 Human keratinocyte cell line인 $\mathrm{HaCaT}$ 세포주를 사용하여 mRNA 발현을 $\mathrm{Kim}$ 의 연구에서 명기된 방법(Kim 등, 2014)에 의해 수행하였다. 전체 RNA 를 UltraspectTM-II RNA system(Biotecx Laboratories, Inc., Houston, TX, USA)을 사용하여 준비하고, single-stranded cDNA를 avian myeloblastosis virus(AMV) reverse transcriptase를 사용하여 합성하였다. 반응액은 $20 \mu \mathrm{L}$ 로 준비하 였으며, $1 \mu \mathrm{g}$ total RNA, 1' reverse transcription buffer(10 $\mathrm{mM}$ Tris- $\mathrm{HCl}, \mathrm{pH} 9.0,50 \mathrm{mM} \mathrm{KCl}, 0.1 \%$ Triton X-100), $1 \mathrm{mM}$ deoxynucleoside triphosphates(dNTPs), $0.5 \mathrm{U}$ RNase inhibitor, $0.5 \mu \mathrm{g}$ oligo(dT), 그리고 $15 \mathrm{U}$ AMV reverse transcriptase 포함하며, $42^{\circ} \mathrm{C}$ 에서 15 분간 배양하고, $99^{\circ} \mathrm{C}$ 에 서 5 분간, 이후 $0-5^{\circ} \mathrm{C}$ 에서 5 분간 배양하였다. Transcript levels은 iQ5 qRT-PCR detection system(Bio-Rad, Hercules, $\mathrm{CA}, \mathrm{USA})$ 으로 분석하였다.

\section{Western blot 분석}

개박하 추출물에 의한 단백질 발현분석은 Kim 등(2014) 
의 연구에서 명기된 방법에 의해 수행하였다. 1 차 항체 (mouse anti-involucrin: 1 : 500, Santa Cruz Biotechnology, Carlsbad, CA, USA; mouse anti- $\beta$-actin: $1: 1,000$, SigmaAldrich Co., St. Louis, MO, USA)와 2차 항체(rabbit anti-mouse IgG-HRP: 1 : 5,000, Santa Cruz Biotechnology, Carlsbad, CA, USA)를 반응시켰다. 단백질밴드는 광 이미 지 시스템(Chemi-Doc image system)(BIO-RAD, Hercules, $\mathrm{CA}, \mathrm{USA}$ )기기를 사용하여 정량하였다.

\section{통계처리}

모든 실험은 독립적으로 3 회 반복 시행하고, 실험결과는 평균표푼평균오차로 표기하였으며, 통계처리는 $\mathrm{GraphPad}$ Prism 5 program(GraphPad Software, Inc., La Jolla, CA, $\mathrm{USA}$ )을 이용하여 $\mathrm{p}$ 값이 0.05 미만일 때 통계적으로 유의 하다고 판단하였다. 일원배치 분산분석(one-way analysis of varience)을 한 후, 각 시료간의 통계적 유의성은 Bonferroni's multiple comparison test를 이용하여 수행하였다.

\section{결과 및 고찰}

\section{개박하 추출물의 세포독성평가}

멜라노마 세포에 개박하 추출물(N. cataria extract, NCE) $10 \mu \mathrm{g} / \mathrm{mL}, 100 \mu \mathrm{g} / \mathrm{mL}, 250 \mu \mathrm{g} / \mathrm{mL}, 500 \mu \mathrm{g} / \mathrm{mL}, 750 \mu \mathrm{g} / \mathrm{mL}$ 의 농도에서 각각 $0 \%, 0.89 \%, 8.80 \%, 18.20 \%, 35.50 \%$ 독성이 나타났다(Fig. 1). 따라서 이후의 실험은 독성이 거의 없는 $100 \mu \mathrm{g} / \mathrm{mL}$ 이하의 농도에서 진행하였으며, 함암효과로서 연구된 개박하 추출물의 논문에서도 독성이 없는 안전한

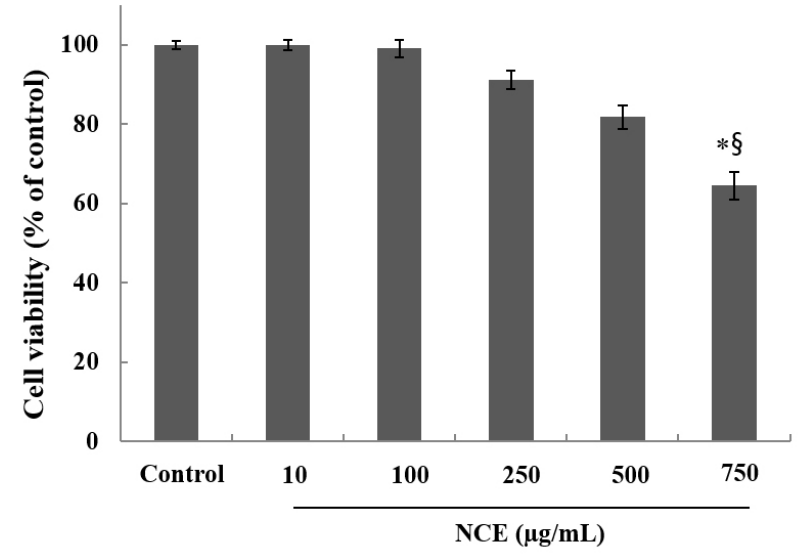

Fig. 1. Cell cytotoxicity of Nepeta cataria extract (NCE) on murine melanoma B16F10 cell.

NCE-untreated group was used as a negative control. Values are presented as mean \pm SEM. Differences were considered statistically significant, ${ }^{*} \mathrm{p}<0.05$ compared to the control group, ${ }^{\S} \mathrm{p}<0.05$ compared to the NCE $10 \mu \mathrm{g} / \mathrm{mL}$ group.
물질로 보고되었다(Fan 등, 2017).

\section{개박하 추출물의 산화방지 활성}

개박하 추출물 시료와 대조구 시료를 각각 $10 \mu \mathrm{g} / \mathrm{mL}$, $50 \mu \mathrm{g} / \mathrm{mL}, 100 \mu \mathrm{g} / \mathrm{mL}$ 의 농도로 제조하여 $\mathrm{DPPH}$ 소거활성 을 측정한 결과(Fig. 2), NCE 각각에 대한 $10 \mu \mathrm{g} / \mathrm{mL}, 50$ $\mu \mathrm{g} / \mathrm{mL}, 100 \mu \mathrm{g} / \mathrm{mL}$ 의 추출물 농도에서 $90.20 \%, 92.70 \%$, $93.70 \%$ 를 보였으며, 대조구와 거의 차이가 없는 $(92.80 \%$, $93.60 \%, 94.50 \%$ ) 라디칼 소거활성을 나타냈다. 또한, 피부 장벽 보호효과로서 보고된 루꼴라(Kim 등, 2014) 추출물의 $50 \%$ 라디칼 소거활성 농도가 $420 \mu \mathrm{g} / \mathrm{mL}$ 를 보이는 것과 비교할 때, 산화방지 소재로서 더 우수한 개박하 추출물의 가능성을 확인할 수 있다.

\section{개박하 추출물의 PPAR-a transcription 활성}

개박하 추출물에 대한 세포독성이 없는 농도에서 PPAR- $\alpha$ transcription 활성을 측정하였다(Fig. 3). PPAR- $\alpha$ 작용제 (agonist)로서 표준물질로 알려져 있는 WY14643(Sigma Chemical Co., St. Louis, MO, USA)을 대조물질로 사용하였 으며(Kim 등, 2014), NCE 추출물 시료의 농도가 증가할수 록 PPAR- $\alpha$ 리간드 결합활성이 증가되는 경향을 보였으며 대조군 대비(3.5)하여 $100 \mu \mathrm{g} / \mathrm{mL}$ 의 $\mathrm{NCE}$ 농도에서 유사한 활성(3.7)을 확인하였다. 다른 천연소재 중 우수한 피부장 벽 보호효과로서 보고된 루꼴라(Kim 등, 2014) 추출물의 경우와 비슷한 활성(3.6)을 보이는 것을 고려하면 본 연구 의 개박하 추출물의 경우 우수한 표피의 분화와 표피 지질 의 합성을 촉진함으로써 에너지 항상성을 조절하는 PPAR- $\alpha$

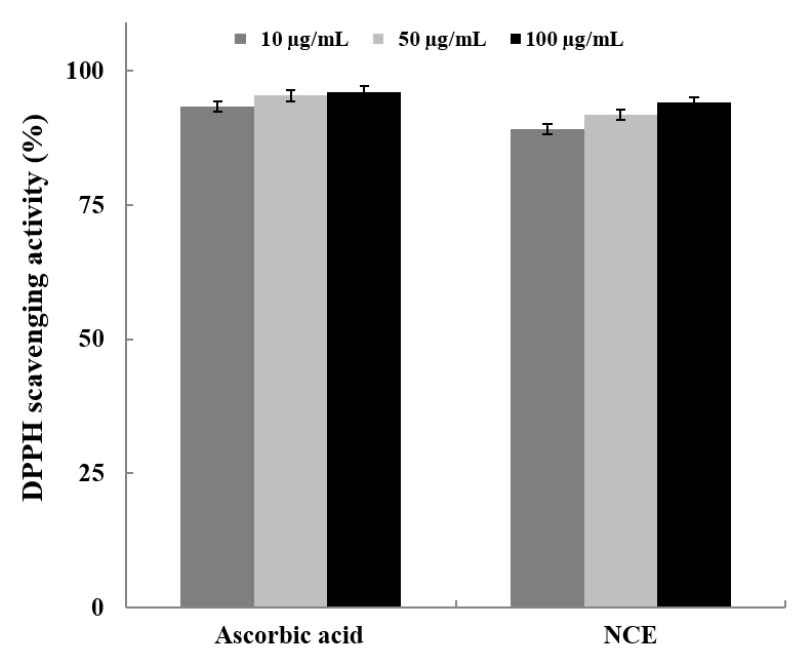

Fig. 2. Anti-oxidant effects of Nepeta cataria extract (NCE). Ascorbic acid was used as a positive control. Values are presented as mean \pm SEM. Differences were considered statistically significant. 


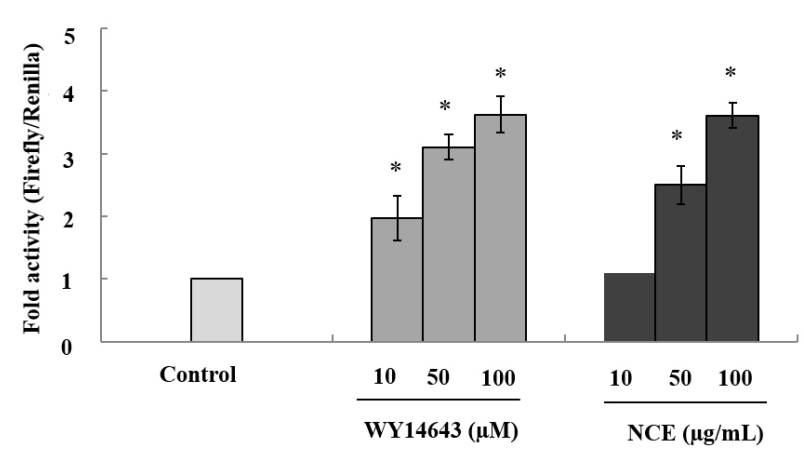

Fig. 3. Transactivation of peroxisome proliferator-activated receptor (PPAR)-responsive element (PPRE) by different concentrations of Nepeta cataria extract (NCE).

WY14643 and no treatment were used as a positive control and as a negative control respectively. Values are presented as means \pm standard error of the mean (SEM). ${ }^{*} \mathrm{p}<0.05$ compared to the untreated control group.

작용제(agonist)로서 가능성을 확인할 수 있다.

\section{개박하 추출물의 filaggrin 발현 효과}

Filaggrin은 정상피부의 가장 바깥층에 다량 존재하며, 피부보호막 형성의 필수요소로 피부의 수분을 유지하고 외부 이물질의 침투를 막아준다. 부족 시, 피부보호막이 깨지면서 이물질이 침투하고, 수분의 증발/손실이 발생하 며, 상태가 악화되면 염증이 발생한다(Del Rosso 와 Kircik, 2013). 개박하 추출물에 의한 fliaggrin 발현에 미치는 영향 을 시험하기 위하여 세포독성이 없는 농도에서 quantitative RTPCR을 측정하였다(Fig. 4). 양성대조군을 대비하여 (0.62배) $100 \mu \mathrm{g} / \mathrm{mL}$ 의 NCE 농도에서 높은 발현을 확인하 였다(1.3배). 그러나, 양성대조군(WY14643)과 $10 \mu \mathrm{g} / \mathrm{mL}$, $50 \mu \mathrm{g} / \mathrm{mL}$ 의 $\mathrm{NCE}$ 농도에서는 무처리 대조군에 비해 낮은

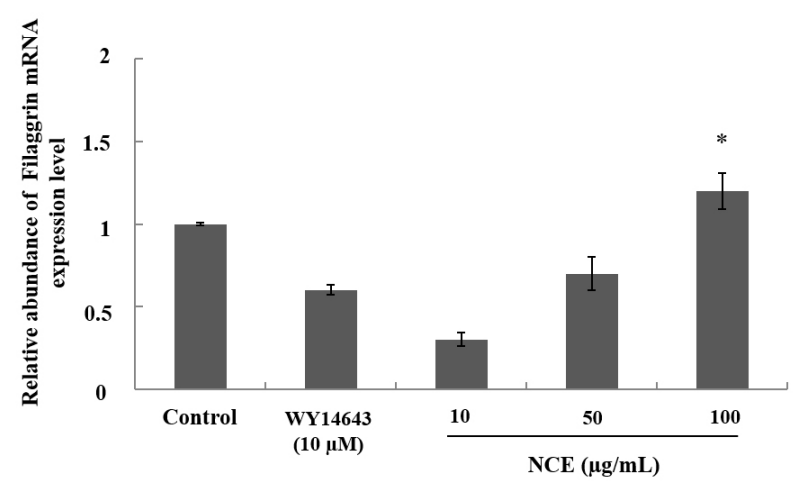

Fig. 4. Effect of Nepeta cataria extract (NCE) on expression of filaggrin.

WY14643 and no treatment were used as a positive control and as a negative control respectively. Values are presented as means \pm standard error of the mean (SEM). ${ }^{*}<0.05$ compared to the untreated group.
발현을 보였으며, 보다 정확한 발현 메카니즘을 확인해 볼 필요가 있다(Kim 등, 2014).

\section{개박하 추출물의 involucrin 발현 효과}

피부장벽 보호 지표물질로서 cornified envelope(CE)에 관련된 단백질인 involucrin(Jensen 등, 2004) 발현에 대한 개박하 추출물의 영향을 측정하였다(Fig. 5). 무처리 대조 군 및 양성대조군인 $1.2 \mathrm{mM} \mathrm{CaCl} 2$ 와 함께 $10 \mu \mathrm{g} / \mathrm{mL}, 50$ $\mu \mathrm{g} / \mathrm{mL}, 100 \mu \mathrm{g} / \mathrm{mL}$ 의 $\mathrm{NCE}$ 농도에서 각각 $198 \%, 221 \%$, $261 \%$ 로 농도가 증가함에 따라 involucrin 발현이 증가되었 으며, $1.2 \mathrm{mM} \mathrm{CaCl} 2280 \%$ 에 비해서는 다소 낮았다. 특히 $100 \mu \mathrm{g} / \mathrm{mL}$ 농도에서는 양성대조군(280\%)과 거의 비슷한 involucrin 발현증가(261\%)를 보였다.

\section{요 약}

본 연구에서 개박하(N. cataria)에 대한 항산화, 세포독 성 및 피부장벽 보호인자 생성 여부, 관련 단백질 발현 등을 연구하여 기능성 소재로서 활용 가능성을 조사하였 다. 개박하 추출물은 낮은 세포독성을 나타냈으며, 세포독 성이 거의 없는 농도에서 개박하 추출물 처리 시, 산화방지

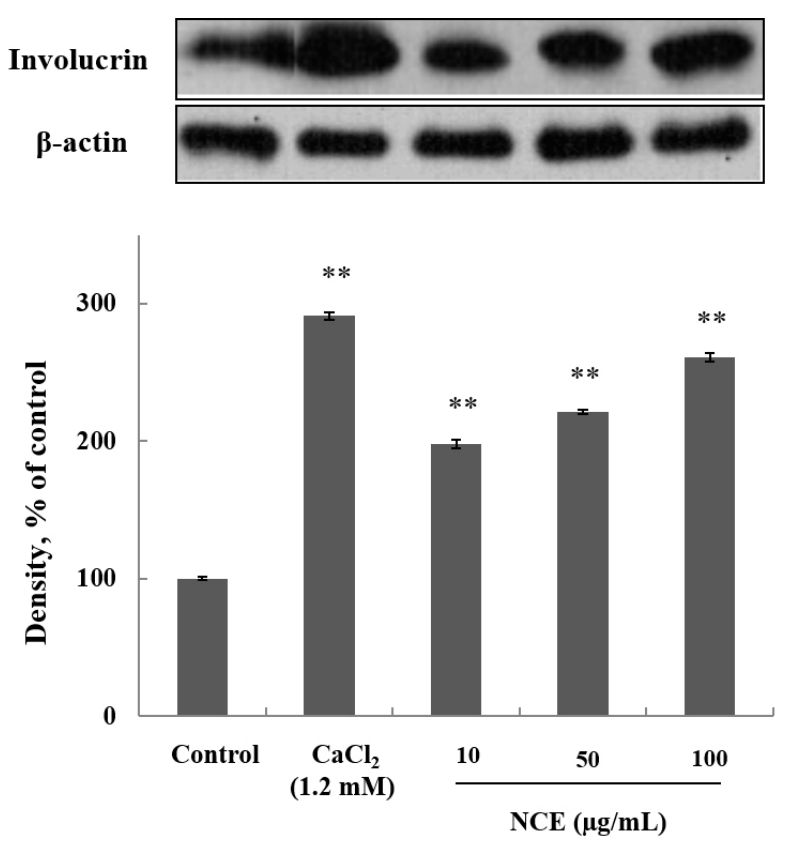

Fig. 5. Effect of Nepeta cataria extract (NCE) on expression of involucrin.

Each signal was quantified by scanning densitometry. $1.2 \mathrm{mM} \mathrm{CaCl}_{2}$ and no treatment were used as a positive control and as a negative control respectively.

Values were nomalized to $\beta$-actin before calculating changes and presented as mean \pm SEM. Differences were considered statistically significant, ${ }^{* *} \mathrm{p}<0.01$ compared to the control group. 
활성과 개박하 추출물 시료의 농도가 증가할수록 PPAR- $\alpha$ 리간드 결합활성이 증가되는 경향을 보여주었다. 개박하 추출물은 피부장벽 보호에 관련된 filaggrin의 발현을 촉진 하였으며 또한, 관련단백질인 involucrin 발현을 향상시키 는 것을 확인하였다. 이와 같은 결과로 미루어 볼 때 개박 하 추출물은 피부장벽 개선 효과를 지닌 기능성 화장품에 천연물 재료로 활용될 수 있다고 사료된다.

\section{감사의 글}

본 연구는 2017년도 교육부와 한국연구재단(NRF)의 이 공분야기초연구지원사업의 지원(2017R1D1A1B03031402) 에 의해 수행되었습니다.

\section{Conflict of interests}

The author declare no potential conflict of interest.

\section{ORCID}

Hyun-Soo Kim https://orcid.org/0000-0003-4596-7701

\section{References}

Ahn JJ, Hwang TY, Kim HS. Study on the physiological activities of Cleyera japonica extract. Kor J Plant Res, 28, 153-157 (2015)

Briganti S, Camera E, Picardo M. Chemical and instrumental approaches to treat hyperpigmentation. Pigm Cell Res, 16, 101-110 (2003)

Del Rosso JQ, Kircik LH. The integration of physiologicallytargeted skin care in the management of atopic dermatitis: Focus on the use of a cleanser and moisturizer system incorporating a ceramide precursor, filaggrin degradation products, and specific "skin-barrier-friendly" excipients.
J Drugs Dermatol, 12, 85-91 (2013)

Fan J, Bao Y, Meng X, Wang S, Li T, Chang X, Yang G, Bo T. Mechanism of modualtion through PI3K-AKT pathway about Nepeta cataria L.'s extract in non-small cell lung cancer. Oncotarget, 8, 31395-31405 (2017)

Hanley K, Jiang Y, Crumrine D, Bass NM, Appel R, Elias PM, Williams ML, Feingold KR. Activators of the nuclear hormone receptors PPAR- $\alpha$ and FXR accelerate the development of the fetal epidermal permeability barrier. J Clin Invest, 100, 705-712 (1997)

Jensen JM, Folster-Holst R, Baranowsky A, Schunck M, Winoto-Morbach S, Neumann C, Schutze S, Proksch E. Impaired spingomyelinase activity and epidermal differentiation in atopic dermatitis. J Invest Dermatol, 122, 1423-1431 (2004)

Kersten S, Desvergne B, Wahli W. Roles of PPARs in health and disease. Nature, 405, 421-424 (2000)

Kim B, Choi YE, Kim HS. Eruca sativa and its flavonoid components, quercetin and isorhamnetin, improve skin barrier function by activation of peroxisome proliferatoractivated receptor (PPAR)- $\alpha$ and suppression of inflammatory cytokines. Phytother Res, 28, 1359-1366 (2014)

Kim HS. Effect of Abelmoschus esculentus extract on anti-melanogenesis and skin barrier function. Korean $\mathrm{J}$ Food Sci Technol, 50, 344-348 (2018)

Ranke J, Molter K, Stock F, Bottin-Weber U, Poczobutt J, Hoffmann J, Ondruschka B, Filser J, Jastorff B. Biological effects of imidazolium ionic liquids with varying chain lengths in acute Vibrio fischeri and WST-1 cell viability assays. Ecotoxicol Environ Saf, 58, 396-404 (2004)

Wang M, Cheng KW, Wu Q, Simon JE. Quantification of nepetalactones in catnip (Nepeta cataria L.) by HPLC coupled with ultraviolet and mass spectrometric detection. Phytochem Anal, 18, 157-160 (2007) 